\title{
Women and Law in South Asia
}

\section{Upasana Mahanta $^{1} \cdot$ Sameena Dalwai $^{1} \cdot$ Albeena Shakil $^{1}$}

Published online: 20 November 2019

(C) O.P. Jindal Global University (JGU) 2019

\section{The theme}

This special issue of the Jindal Global Law Review (JGLR) is themed 'Women and Law in South Asia'. The term 'South Asia' often evokes a sense of shared civilizational, cultural and historical moorings including experiences of colonialism, decolonization, the partition and modern nation-state formation. While South Asia, a complex geo-political region, is largely viewed as existing 'elsewhere', created and sustained mainly by area studies programmes in the west, this special issue comprises of several contributions which negotiate this complex terrain with refreshing ease. This is significant because the challenges of focusing on South Asia are many. For one, within the region itself, South Asia remains an under-researched area, with few studies focusing on law and even fewer focusing on women and law. One early volume we could look towards was Violence, Law and Women's Rights in South Asia edited by Savitri Goonesekere in 2004. The collection examined the experiences of inheriting legal derivatives of British colonial laws in Sri Lanka, Pakistan and India, often with women being at the heart of the contradiction with ethnic, religious or customary laws. Pointing to the "reality of "failed' legal systems," 1 as far as gender-based violence was concerned, the contributors called for prioritized reforms in accordance with the Convention of the Elimination of Discrimination Against

\footnotetext{
1 Savitri Goonesekere (ed), Violence, Law and Women's Rights in South Asia (Sage Publications 2004) 76.
}

Upasana Mahanta-Associate Professor, Sameena Dalwai-Associate Professor, Albeena Shakil— Associate Professor

Albeena Shakil

ashakil@jgu.edu.in

Upasana Mahanta

umahanta@jgu.edu.in

Sameena Dalwai

sdalwai@jgu.edu.in

1 Jindal Global Law School, Sonipat, India 
Women (CEDAW) and the Convention on the Rights of the Child (CRC). The volume also assessed law as a "double-edged sword"2 for women.

A 2012 collection, Comparative Constitutionalism in South Asia, edited by Sunil Khilnani, Vikram Raghavan and Arun K. Thiruvengadam saw the potential of evolving comparative constitutionalism towards "South Asia's own future potential as a region that is more integrated and more at peace with itself." 3 Mark Tushnet and Madhav Khosla in their 2015 volume Unstable Constitutionalism: Law and Politics in South Asia, identified South Asia as a region of "vibrant if rambunctious constitutionalism," " with "recurring tensions that lie at the intersection of law and politics." The editors saw constitutional instability as a consequence of socio-political pressures and identified its structures and forms. More recently, a series of eight volumes on "Sexual Violence and Impunity in South Asia"6 has been underway by the Delhi-based Zubaan Publishers. Penned on different themes by feminists from India, Pakistan, Bangladesh, Nepal and Sri Lanka, the series comprising of authored and edited volumes offers invaluable insights that are nation-specific with a scope for comparison.

The present volume is a modest step in this continuing direction, with a collection of articles, interviews, case notes and book reviews largely engaging with contemporary legal issues that women in South Asia encounter. While some of the papers have a broad comparative framework looking at two or more South Asian legal contexts, others are located within the domestic legal frameworks of India. Written independently, the contributions often speak to each other, evaluating each of the proposed categories of 'women', 'law' and 'South Asia' as well as offering prospects of engendering legal reforms and building feminist solidarities. One of the important benchmarks of conceiving South Asia is the similarity in the status of women across the region. Lived experiences of women in South Asia often navigate the volatility of individual and group rights, honor and shame, purity and pollution, customary practices and modern citizenship rights, extreme poverty, illiteracy, health vulnerabilities, armed conflict, gender based violence, etc. These negotiations are deeply rooted in the social realities of religion, caste, race, ethnicity, class, age, and disability. While a few contributors have sought to identify the homogeneity in the lived experiences of women in South Asia, others have also viewed the category of women as multiple, changing and contested, deeply interspersed with other forms of social exclusion including caste, class, religion, and sexuality. Within this context, the contributions to this volume raise poignant questions on universalism

\footnotetext{
2 ibid 7. Chandni Ghosh, 'Foreword'.

3 Sunil Khilnani, Vikram Raghavan and Arun K. Thiruvengadam (eds), Comparative Constitutionalism in South Asia (Oxford University Press 2013) 22.

4 Mark Tushnet and Madhav Khosla (eds), Unstable Constitutionalism: Law and Politics in South Asia (Cambridge University Press 2015) 4.

5 ibid 5.

6 Some indicative titles in the Zubaan series are: Disputed Legacies: The Pakistan Papers; Breaching the Citadel: The India Papers I; The Search for Justice: The Sri Lanka Papers; Fault Lines of History: The India Papers II; A Difficult Transition: The Nepal Papers; Of the Nation Born: The Bangladesh Papers; Undoing Impunity: Speech After Sexual Violence.
} 
and cultural relativism in law and also navigate the tensions between individual and group rights.

Moreover, law itself is a complex terrain to navigate in South Asia. On the one hand, there is a prevalence of extra-judicial and informal dispute resolution mechanisms, largely rooted in patriarchy. On the other, there is a male-centric legal ethos in the formal legal systems that routinely exclude and marginalize women. The formal and the informal, however, are not necessarily mutually exclusive and often operate in tandem with each other. This is significant because, in societies where customs are deeply intrinsic to social and political life, states often tend to take on the role of the patriarch. In addition, this exists in a political context where an unprecedented number of women have historically headed governments in the region creating an illusion of considerable political empowerment of women. Yet, women in South Asia continue to primarily look towards law, and not politics, for redressal. The women's movements too have put a heavy emphasis on addressing the oppression of women through legislative advancements. While law has been an instrument to perpetuate the dependent status of women as citizens, women have also been using law as a weapon to challenge existing power hierarchies. Existing laws may be hostile to women's interests, appeal to inherent 'womanly' qualities, force political subjects to fight as women, but they also end up making concessions to women, albeit reluctantly.

Rooted largely in a transdisciplinary approach, this volume integrates conceptual, theoretical and methodological tools, which cut across the disciplinary boundaries of the three editors. It has been a truly exciting and inspiring journey for us to work towards putting this issue together, which is a culmination of a series of intense discussions, debates, deliberations and contestations. Our "feminist curiosity" stems from seeking to understand the workings of law in South Asia from a woman's standpoint, pursuing explanations for women's marginalization within the law and identifying strategies for change. Following Enloe, we are committed to taking women's lives seriously, where 'seriously' connotes “listening carefully, digging deep, developing a long attention span, being ready to be surprised... a feminist curiosity finds all women worth thinking about, paying close attention to..."8

In a vitiated Indian context of muscular majoritarian assertions, the looming specter of an exclusionary National Registry of Citizens and the Citizenship Amendment Bill, the recent Ayodhya verdict undermining secularism, growing militarization and subversion of democratic rights in Kashmir, uncertain future of the Naga peace talks, growing discourse of claims to victimhood by dominant caste groupings and a creeping threat to constitutional foundations, working on this volume has encouraged us towards resilience and hope. Our investment in women, law and South Asia is not just a matter of academic concern, but also stems from our commitment to these categories as potentially vital to contesting dominant narratives. While women continue to remain a tangible yet elusive category, the promise

\footnotetext{
7 Cynthia Enloe, The Curious Feminist: Searching for Women in a New Age of Empire (University of California Press 2004).

8 ibid 3.
} 
of law persists as a daunting prospect rather than an assurance, and South Asia seems to exist more elsewhere than within the region, our attempt in this volume is to present a thought-provoking collection that may inform contemporary debates. We would like to extend our heartfelt gratitude to all the people who encouraged, supported and guided us in putting this Special Issue together - Professor Vishwas Devaiah for bringing the three editors together and helping us in conceptualizing the Issue, Professor Oishik Sircar and Arun Sagar for their sustained support throughout this journey and for being always accessible, Professor Saptarshi Mandal for some very useful ideas, all our contributors for their time and effort and the faith they reposed on us, all our reviewers (Professor Dipika Jain, Professor Keerty Nakray, Professor Mohsin Alam Bhat, Professor Rohini Sen, Professor Rashmi Raman, Professor Alliya Anjum, Professor Shama Banoo Hussain Abbasi) for giving us their valuable time, and last but not the least all our student reviewers for their tireless work, which has made this Special Issue possible. We sincerely hope that the readers of this volume will benefit from the collection as much as we have.

\section{Notes on contributions}

This special issue carries seven papers, two interviews, two case notes and two book reviews. The very first paper by Jane Krishnadas draws upon her fieldwork during a five-year rehabilitation period following the 1993 Maharashtra earthquake in India. She problematizes the conception of women survivors as homogenous legal subjects, who in fact negotiate a complex terrain of justice and law between "families, [communities], civil society, public, private and third sector agents within State and the international community." Her paper proposes a transformative framework with the creation of women's agency, wherein victims become survivors, beneficiaries turn into contributors and objects transform into agents of change. Theoretically examining feminist legal strategies from the east to the west, Krishnadas argues for a focus on the individual woman's stand, experience and response to everyday crisis instead of trying to construct women's identity within static legal systems and dominant discourses.

Theoretically engaging with various comparative legal approaches in their paper, namely, third world approaches to international law (TWAIL), feminist approaches to international law (FtAIL), sex-based (SBD) and gender-based (GBD) discrimination frameworks, as well as 'hard' and 'soft' international laws, Sai Ramani Garimella and Parthiban B. underscore the shortcomings of understanding discrimination against women in South Asia. Freedom of religion or belief, they argue, is a frequent resort of states in the region to resist international laws guaranteeing the rights of women. The paper examines various personal laws and customary practices prevalent in Bangladesh, India, Pakistan, Afghanistan and Sri Lanka, which are steeped in deep gender bias. The authors argue that the defense of freedom of religion vis-à-vis women in the region is nothing but a euphemism for religious misogyny, which remains the key impediment in the path of engendering legal reforms in South Asia. 
Saumya Uma's paper explores major twenty-first century struggles on issues of violence against women in the region, namely, domestic violence, honor killings, acid violence, chhaupadi, marital rape, two-finger tests, extra-judicial punishments, informal dispute resolution and justice for women in conflict situations in India, Pakistan, Bangladesh, Nepal and Sri Lanka. Uma traces similarities in the struggles of respective women's movements, each of which adopt political, democratic and legal strategies against both state as well as non-state actors. Identifying parallel issues, similar roadblocks and legislative debates, albeit in different sequences, her paper makes a case for drawing upon more successful struggles from across neighboring borders for building upon the potential for "cooperation, solidarity and sisterhood" among women in South Asia.

Taking another route towards the universalism versus cultural relativism debate, Bhumika Nanda in her paper evaluates India's response to the latest round of the Universal Periodic Review (UPR) conducted by the United Nations High Commissioner for Human Rights in 2017, wherein only 152 of the 250 recommendations were accepted by India. Focusing especially on those pertaining to discriminatory customary practices, sexual violence, sexual orientation and gender identity of LGBT citizens, Nanda notes a contradiction between the response of the Indian government and the Indian courts. Court judgements and rulings, she argues, are better at striving towards a "minimum core" rights approach, whereas legislations and government policies betray greater resistance to universal human rights paradigms. With women's movements also negotiating these contradictions, Nanda argues for a decisive revision in the approach of the Indian government towards international human rights.

Devyani Srivastava devotes her attention to examining another wing of the state, i.e., the Indian police, more specifically, its recent policy focus on increasing the representation of women. Her paper evaluates different aspects like the differential reservation policies for women in intake, role of women in dedicated units, all-women police stations or women PCR vans as well as transfers, postings and promotions for women. The apparent "gendering" of the police force, she argues, is actually based on reinforcing stereotypes, discrimination and exclusion, thereby limiting and defining the scope of women's work within the police. She makes a case for gender-mainstreaming through the introduction of substantive changes in organizational cultures with a comprehensive focus on the inclusion of women in order to create more effective and gender-sensitive policing systems.

Sai Thakur and Shewli Kumar's paper locates sexual harassment in academic spaces in the backdrop of falling female labour force participation rates, which in the South Asian region are among the lowest in the world. With both India and Pakistan sharing the lowest rates in the region at 24 per cent each, the paper examines the paradox of the overwhelming bulk of women's work being informal while the law focuses on formal work places. The authors compare how similar laws formulated first in Pakistan and then in India required subsequent policy revisions to address sexual harassment in higher education institutions (HEI). The paper then shifts focus to delineate first-hand experiences of the challenges and remedies for creating more effective redressal processes in HEI's in India. 
Taking this conversation forward, Sandhya Gawali's paper compares the recent evolution of two ongoing young women's movements based in HEIs in India-Pinjra Tod (Break the Cage) and \#MeToo campaigns. While the Pinjra Tod campaign made the demand for the creation of Internal Complaints Committees (ICC) within institutions, the \#MeToo campaign has been critical of ICCs and their futility. Tracing fractures based on digital divide, generation gap and most significantly, between Dalit/Bahujan/Adivasi non-binary feminists and cis-Savarna feminists, Gawali seeks to reconcile the struggle over the legitimacy of feminist knowledge between the two divergent trends. Sharing social-media and interview-based insights by young women and underscoring the need to reform the due-processes of ICCs, her paper proposes that a focus on "power" in HEIs may provide the scope to understand the common angst of young women.

The volume also carries two interviews: one with Prabha Kotiswaran and another with V. Geetha. In her conversation with Oishik Sircar, Kotiswaran expresses skepticism about the categories of both women and South Asia. Sharing her experiences of research across three continents into areas like sex-work, anti-trafficking and rape laws, she argues against the possibility of both avoiding men or transgender persons for engagement, and maintaining any strict locational focus. Kotiswaran's reflections on inadequate feminist scholarship in India on domestic work or social reproduction, "invisible, unremunerated, and unrecognized unpaid" work in the academia, the pros and cons of "governance feminism," recent \#Metoo mobilizations, the lived experience of being a lawyer and a feminist, rethinking materialist feminism with greater cooperation between class and gender movements, will be exciting for any reader.

Bringing forth the intersections of caste, gender and power in South Asia, V. Geetha in conversation with the three editors, locates questions relating to work, family, kin and society, keeping endogamy as the bedrock of her analysis. Dealing with a wide array of issues ranging from the Khairlanji murders, the Unnao rape case, the Shopian rape and murder, the Vachathi mass assault of Adivasi women, as well as laws like the AFSPA and the UAPA that are abused and misused, or the Prevention of Atrocities Act against SCs and STs, which is underused, Geetha draws attention to the particularities of sexual impunity in India. Her theoretically rich reflections on the evolution and trajectory of Dalit feminisms offer invaluable insights into understanding the relationship between women and law in India.

The volume also offers two case notes. Nehmat Kaur's note on Hadiya discusses the infamous case of a 24 year-old Hindu woman who married a Muslim man and converted to Islam. Even with subsequent redressal by the Supreme Court, the courts were paternalistic and treated an adult woman as a vulnerable subject without the capacity to consent. They overreached their jurisdiction in the context of the myth of 'love jihad' and suspicions towards the Muslim community. Eysha Marysha has written about the case of Independent Thought v. Union of India in which Exception 2 of Section 375 of the Indian Penal Code has been challenged. This provision made an exception from punishment for statutory rape for the husband of minor bride (between the ages of 15 to 18 years), as opposed to rape of a minor child, not being a wife, as per the Protection of Children from Sexual Offences Act, 2012. Despite rape laws being amended by the government, the deliberate choice to retain this provision of under-age marital rape required the intervention of the Supreme Court to 
read down the said provision to rectify the artificial difference created between a married and an unmarried minor girl.

In addition, this volume includes two interesting book reviews of Anita Ghai's edited volume Disability in South Asia: Knowledge and Experience (2018) and Laila Ashrafun's Women and Domestic Violence in Bangladesh: Seeking a Way Out of the Cage (2018). Deblina Dey and Saptarshi Mandal, through their respective reviews, offer critical insights into the socio-legal lives of women in South Asia.

Publisher's Note Springer Nature remains neutral with regard to jurisdictional claims in published maps and institutional affiliations. 